\title{
Effect of Alloy Chemistry on the High Temperature Strengths and Room Temperature Fracture Toughness of Advanced Nb-Based Alloys*1
}

\author{
Masakuni Fujikura ${ }^{1}$, Akio Kasama*2, Ryohei Tanaka ${ }^{2}$ and Shuji Hanada ${ }^{3}$ \\ ${ }^{1}$ Japan Ultra-high Temperature Materials Research Institute (JUTEMI), Gifu 507-0801, Japan \\ ${ }^{2}$ Japan Ultra-high Temperature Materials Research Institute (JUTEMI), Ube 755-0001, Japan \\ ${ }^{3}$ Institute for Materials Research, Tohoku University, Sendai 980-8577, Japan
}

\begin{abstract}
High temperature strength and room temperature fracture toughness of Nb-based alloy system were investigated to explore a candidate material for gas turbine use at $1773 \mathrm{~K}$ as a function of chemical compositions. $0.2 \%$ proof stress at $1773 \mathrm{~K}$ and the fracture toughness were studied for the solid-solution hardening Nb-Mo-W alloys and the $\mathrm{Nb}_{5} \mathrm{Si}_{3}$-reinforcing Nb-Si-Mo-W-Hf alloys, and were found that the $0.2 \%$ proof stress linearly increases with increasing $(\mathrm{Mo}+1.5 \mathrm{~W})$ content and also increases with volume fraction of $\mathrm{Nb}_{5} \mathrm{Si}_{3}$, while the fracture toughness decreases with $(\mathrm{Mo}+1.5 \mathrm{~W})$ content in solid-solution. The critical content for a ductile-to-brittle transition to occur is at $(\mathrm{Mo}+1.5 \mathrm{~W})$ content of $33.5 \mathrm{~mol} \%$ together with molybdenum content of $15 \mathrm{~mol} \%$. Nb-16Si-5Mo-15W-5Hf alloy with a microstructure consisting of $50 \mathrm{vol} \%$ solid-solution and $50 \mathrm{vol} \% \mathrm{Nb}_{5} \mathrm{Si}_{3}$, obtained by optimizing the alloy chemistry without a significant loss of high temperature capability and ductility, and by modifying with $5 \mathrm{Hf}-5 \mathrm{C}$ addition, was found to demonstrate an unprecedentedly excellent creep resistance and also a creep rupture strength exceeding the target strength of $150 \mathrm{MPa}$ and above at $1773 \mathrm{~K}$ for $100 \mathrm{~h}$.
\end{abstract}

(Received September 24, 2003; Accepted December 19, 2003)

Keywords: niobium alloy, silicide, composite alloy, high temperature, strength, fracture toughness, ceep resistance, creep rupture strength

\section{Introduction}

Future aerospace as well as gas turbine applications will require advanced materials with ever-increasing temperature-endurance and load-bearing capabilities for improved turbine performance, such as higher turbine inlet temperature (TIT), and higher thermal efficiency to reduce the emission of carbon dioxide. Currently employed Ni-based superalloys have reached their temperature limitation with operating temperature greater than $90 \%$ of their melting temperatures. ${ }^{1)}$ Therefore, the developments of further advanced cooling and/or thermal barrier coating technologies are required, which cause some extent of thermal efficiency loss. So Nibased superalloy will not be able to meet the higher temperature requirements of future advanced gas turbine systems.

$\mathrm{Nb}$-based alloys have the potential for meeting the above requirements because of relatively low density, $1000 \mathrm{~K}$ higher melting temperature than those of Ni-based superalloys, and attractive high temperature strength properties combined with moderate room temperature ductilities. Niobium-alloy systems have been extensively explored for a number of applications such as space nuclear power systems, aerospace structures and aircraft gas turbine uses. ${ }^{2)}$ For developing further advanced turbine engine systems with much higher temperature capability, some Nb-based alloys composed of $\mathrm{Nb}-\mathrm{Ti}-\mathrm{Al}$ modified with chromium or hafnium and with silicon, chromium, aluminium, and hafnium have been studied, and are found to have attractive properties in toughness and strength. ${ }^{1,3)}$ However, the target temperatures of these alloys are only 1373-1473 K.

The purpose of this study is to investigate the strength and

\footnotetext{
${ }^{* 1}$ Research and Development of Advanced Nb-Based Alloys for Structural Applications at Ultra-High Temperature.

*2Present address: Department of Materials Science and Engineering, Kurume National College, Kurume 830-8555, Japan.
}

toughness of niobium-based alloy systems as a function of chemical compositions, and to propose candidate alloys with the unprecedentedly high endurance temperature, $1773 \mathrm{~K}$. This study is to obtain the following aimed high temperature strengths and room temperature fracture toughness including disscussion on the strengthening and toughening mechanisms.

- strength at $1773 \mathrm{~K}: 450 \mathrm{MPa}$ or above

- specific strength (density-normalized $0.2 \%$ proof stress) at $1773 \mathrm{~K}: 50 \mathrm{MPa} / \mathrm{Mg} / \mathrm{m}^{3}$ or above, corresponding to $0.2 \%$ proof stress of $450 \mathrm{MPa}$ for the density of being $9.0 \mathrm{Mg} / \mathrm{m}^{3}$.

- creep rupture strength at $1773 \mathrm{~K}$ for $100 \mathrm{~h}: 150 \mathrm{MPa}$ or above

- fracture tougthness at room temperature: $10 \mathrm{MPa} \cdot \mathrm{m}^{1 / 2}$ (for reference)

As for oxidation-resistance, a newly developed concept for oxidation-resistant coating technology, which is applicable to Nb-based alloys at the temperature above $1473 \mathrm{~K}$ was explored and reported elesewhere, ${ }^{4)}$ is not included in this paper.

\section{Experimental Procedure}

\subsection{Materials preparation}

The materials studied in this investigation were ternary $\mathrm{Nb}-\mathrm{Mo}-\mathrm{W}$ solid solution (Nbss) alloys and quaternary $\mathrm{Nb}-\mathrm{Si}$ Mo-W Nbss $/ \mathrm{Nb}_{5} \mathrm{Si}_{3}$ silicide alloys. Hafnium ${ }^{5)}$ and carbon ${ }^{6}$ were selected as strengthening and toughening elements. On adding hafnium, the same amount (mol percent) of carbon was also added as $\mathrm{NbC}$. The purities of starting raw materials were (in mass\%) $99.9 \% \mathrm{Nb}, 99.9 \%$ Mo, $99.9 \% \mathrm{~W}, 99.99 \%$ $\mathrm{Si}, 98 \% \mathrm{Hf}$ and $99 \% \mathrm{NbC}$.

The Nb-based alloys were processed by arc-melting under an argon gas atmosphere in a water-cooled copper-hearth using a non-consumable tungsten electrode. The arc-melted ingots were reheated at least five times to ensure chemical 
homogenity. The specimens were heat-treated at $1973 \mathrm{~K}$ for $48 \mathrm{~h}$ followed by furnace cooling to room temperature.

\subsection{Microstructure observations}

Scanning electron microscopic (SEM) studies were performed on the polished and the etched cross section by secondary or backscattered electron image (BEI) using a Hitachi S-800 scanning electron microscope operating at $15 \mathrm{kV}$. After fracture testing, the fracture surface was characterized using SEM fractography. Thin foils for transmission electron microscopic (TEM) studies were prepared by grinding to $60 \mu \mathrm{m}$ thick with emery paper, followed by dimpling to $40 \mu \mathrm{m}$ thick, and then were thinned by ionmilling to electron transparency. TEM observations were performed using a Hitachi $\mathrm{H}-800$ electron microscope at an accelerating voltage of $200 \mathrm{kV}$. The constituent phases and their compositions were determined by using an energydispersive spectroscopy (EDS) (Kvex 8000 in the SEM and a Horiba EMAX 3000 in the TEM).

\subsection{Mechanical testing}

The dimensions of tensile and compressive test specimens were $10 \mathrm{~mm}$ gage length with $3 \mathrm{~mm} \times 3 \mathrm{~mm}$ cross section, and $6 \mathrm{~mm}$ height with $3 \mathrm{~mm} \times 3 \mathrm{~mm}$ cross section, respectively. These specimens were sectioned by electric discharge machining (EDM) and mechanically polished using $\mathrm{SiC}$ paper and $\mathrm{Al}_{2} \mathrm{O}_{3}$ particles with water. Tensile and compressive tests were carried out using a MTS 808 and an Instron 8500 testing machine in an argon atmosphere at temperatures up to $1773 \mathrm{~K}$ and a strain rate of $3 \times 10^{-4} \mathrm{~s}^{-1}$. The fracture toughness, $K_{\mathrm{Q}}$, was determined by three-point bend testing utilizing single-edge notch specimen at a crosshead speed of $0.5 \mathrm{~mm} / \mathrm{min}$ following ASTM-E399-1987 standard except for fatigue-precracking. The bend bar dimensions for $K_{\mathrm{Q}}$ tests were $30 \mathrm{~mm}$ long $\times 3 \mathrm{~mm}$ wide $\times 6 \mathrm{~mm}$ thick, and the EDM notch dimensions were $3 \mathrm{~mm}$ deep $\times 0.05 \mathrm{~mm}$ root radius. $K_{\mathrm{Q}}$ was obtained by the following equation:

$$
K_{\mathrm{Q}}=\left(P_{\mathrm{Q}} S / B W^{3 / 2}\right) \times \mathrm{f}(a / W)
$$

where $P_{\mathrm{Q}}$ is load, $S$ is applied load span, $B$ is thickness, $W$ is height, $a$ is notch depth, and $a / W$ is $0.45 \sim 0.55$.

High temperature creep tests were carried out on five ultrahigh temperature creep testing machines, Toshin HCTT3000 , at temperatures between $1473 \mathrm{~K}$ and $1773 \mathrm{~K}$ under nominal stresses from 10.5 to $200 \mathrm{MPa}$ in an argon atmosphere. The purity of argon gas used was $99.999 \%$. The tungsten heating elements and $\mathrm{SiC}$ hot jigs to transmit the applied stress to test piece were adopted. The dimensions of tensile creep specimens were $10 \mathrm{~mm}$ gage length with $3 \mathrm{~mm} \times 3 \mathrm{~mm}$ cross section and four integral flags (upper and lower flags at the both side of the test piece) were mechanically processed for continuous monitoring of creep displacement between upper and lower flags. The compressive creep specimen was the same in size as that of the previously mentioned compression test.

The creep strain measurement at elevated temperatures up to $1773 \mathrm{~K}$ was one of the most challenging problems, because the usual contact-type extensometer can not be used, and any alternative device was not commercially available. A new optical-type methodology for accurate creep strain measure-

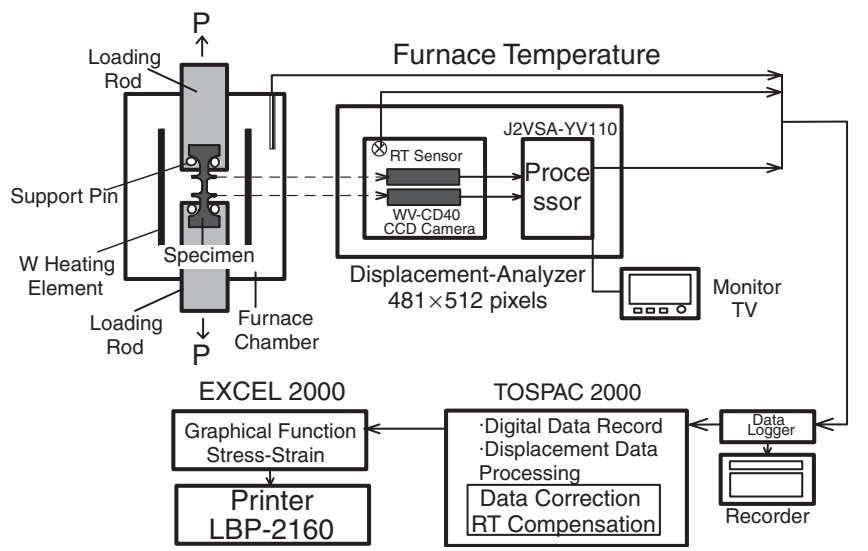

Fig. 1 Schematic diagram of optical-type Thermal-Image-ProcessingDisplacement-Analyzer extensometry system.

ment up to $2273 \mathrm{~K}$ has been developed in our laboratory (JUTEMI) which includes CCD (charge coupled device) cameras with $481 \times 512$ pixels resolution and also includes a controlling function to compensate for strain fluctuation with the change in room temperature. This optical extensometry system, in which strain was continuously measured from change in the distance between the gravity centers of upper and lower flags, was found to work well for the present investigation. Figure 1 shows the schematic diagram of the optical extensometry system.

\section{Results and Discussion}

\subsection{Nb-Mo-W solid-solution alloys}

The high temperature strength properties especially at target temperature of $1773 \mathrm{~K}$ are examined for $\mathrm{Nb}$-based $\mathrm{Nb}$ Mo-W alloys and Nb-Mo-W-5 mol\% Hf alloys (henceforth denoted as Nb-Mo-W-5Hf alloys). Figure 2 shows $0.2 \%$ proof stresses, $\sigma_{0.2}$, in compression tests against $(\mathrm{Mo}+1.5 \mathrm{~W})$ content in mol\%. A linear relationship between the $\sigma_{0.2}$ and $(\mathrm{Mo}+1.5 \mathrm{~W})$ content in the range of $5 \sim 15 \% \mathrm{Mo}$ and $5 \sim 30 \% \mathrm{~W}$ could be found, which can be expressed as the following equation:

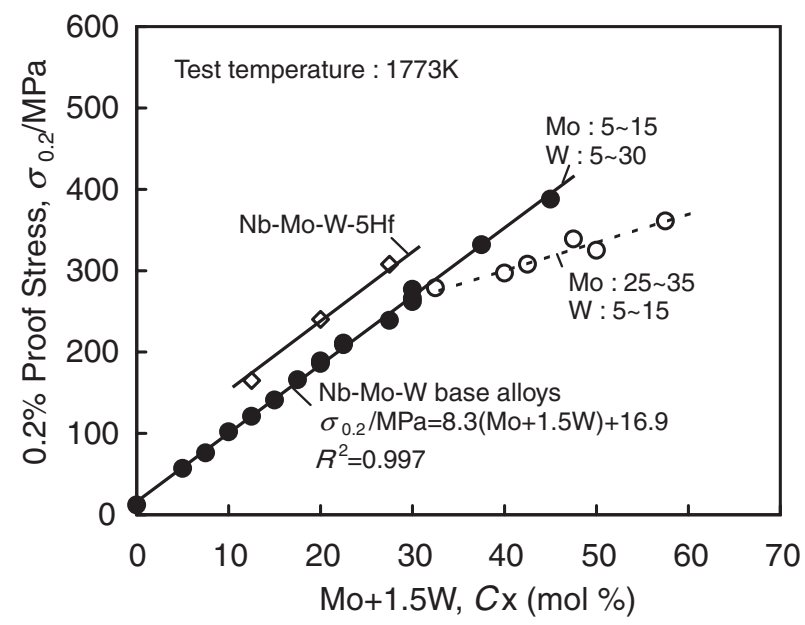

Fig. 2 Plots of compressive $0.2 \%$ proof stress, $\sigma_{0.2}$, for $\mathrm{Nb}-\mathrm{Mo}-\mathrm{W}$ alloys and $\mathrm{Nb}-\mathrm{Mo}-\mathrm{W}-5 \mathrm{Hf}$ alloys at $1773 \mathrm{~K}$ as a function of (Mo+1.5W) content. 


$$
\sigma_{0.2} / \mathrm{MPa}=8.3(\mathrm{Mo}+1.5 \mathrm{~W})+16.7, \quad R^{2}=0.997
$$

Figure 2 also indicates that $0.2 \%$ proof stresses of $\mathrm{Nb}-\mathrm{Mo}-\mathrm{W}$ alloys containing $25 \sim 35 \%$ Mo and $5 \sim 15 \% \mathrm{~W}$, together with $(\mathrm{Mo}+1.5 \mathrm{~W})$ content over $32.5 \%$ are lower comparing to those of alloys with Mo content of $15 \%$ and less at the same $(\mathrm{Mo}+1.5 \mathrm{~W})$ content. Moreover, SEM observations on the $\mathrm{Nb}-25 \sim 35 \mathrm{Mo}-5 \sim 15 \mathrm{~W}$ alloys with $(\mathrm{Mo}+1.5 \mathrm{~W})$ content over $32.5 \%$ after compression test at $1773 \mathrm{~K}$ exhibited remarkable intergranular fracture behaviors, while $\mathrm{Nb}-5 \sim 15 \mathrm{Mo}-5 \sim 30 \mathrm{~W}$ alloy group and $\mathrm{Nb}-25 \mathrm{Mo}-5 \mathrm{~W}$ alloy with $(\mathrm{Mo}+1.5 \mathrm{~W})$ content of $32.5 \%$ exhibited predominant transgranular fracture mode. A previous study on $\mathrm{Nb}-0 \sim 35 \mathrm{Mo}-5 \mathrm{~W}$ alloys with a constant tungsten content ${ }^{6)}$ exhibits that $0.2 \%$ proof stress increases with increasing molybdenum content up to $15 \%$ both in tension and in compression. With further molybdenum addition, the $0.2 \%$ proof stress in compression still reveals an increasing tendency, whereas molybdenum addition more than $15 \%$ causes the decrease in the strength in tension, and also the change in the fracture behavior from transgranular mode to intergranular mode accompanying preyield fracture is observed. In the present study, the oxygen contents of the Nb-Mo-W alloys in the range of $10 \sim 35 \%$ Mo and $5 \sim 15 \% \mathrm{~W}$ were measured as $71 \sim 128$ mass ppm and those for all $\mathrm{Nb}-0 \sim 35 \mathrm{Mo}-5 \mathrm{~W}$ alloys were reported to be about 200 mass ppm. Therefore the lowering of increasing degree of $0.2 \%$ proof stress in compression (Fig. 2), and the notable effect of molybdenum addition, from positive to negative contributions to the strength in tension, on $\mathrm{Nb}$ $0 \sim 35 \mathrm{Mo}-5 \mathrm{~W}$ alloys at $1773 \mathrm{~K}^{6}$ ) can not be explained by oxygen relating fracture characteristics. Instead, the $0.2 \%$ proof stress for ternary Nb-Mo-W alloys could be interpreted in term of a competitive relationship between solid-solution hardening and the cohesive strength weakening at grain boundary due to molybdenum and tungsten additions. So some explanation is necessary for the results that the decrease in increasing rate of $0.2 \%$ proof stress in compression (Fig. 2) and a significant loss of the strength in tension ${ }^{6)}$ occur at $1773 \mathrm{~K}$ over a certain critical amount of alloy additions, accompanying the change in dominant fracture mode from transgranular type to intergranular type. One possible interpretation for the grain boundary fracture to be promoted would be that the strength of grain boundary decreases with increasing alloy content, whereas the strength of grain interior increases due to solid-solution hardening, resulting in the much lower strength of grain boundary than that of grain interior. The formation of molybdenum oxide at grain boundary especially with low melting temperature, ${ }^{7)}$ and the strong anisotropy of grain boundary bonding are enumerated as factors lowering the grain boundary strength. Accordingly, more detailed studies are necessary to understand sufficiently the effect of metallurgical factors such as alloy additions, test temperature and manufacturing procedures on the strength characteristics at high temperature on the basis of grain boundary structure and chemistry.

The addition of $5 \mathrm{Hf}-5 \mathrm{C}$ are effective to raise the $0.2 \%$ proof stress for $\mathrm{Nb}-5 \mathrm{Mo}-5 \mathrm{~W}$ and $-15 \mathrm{~W}$ alloys at $1773 \mathrm{~K}$ as shown in Fig. 3. The increments in $0.2 \%$ proof stress due to $5 \mathrm{Hf}-5 \mathrm{C}$ addition are $44 \mathrm{MPa}$ for $\mathrm{Nb}-5 \mathrm{Mo}-5 \mathrm{~W}$ alloy and $73 \mathrm{MPa}$ for $\mathrm{Nb}-5 \mathrm{Mo}-15 \mathrm{~W}$ alloy, approaching a saturated

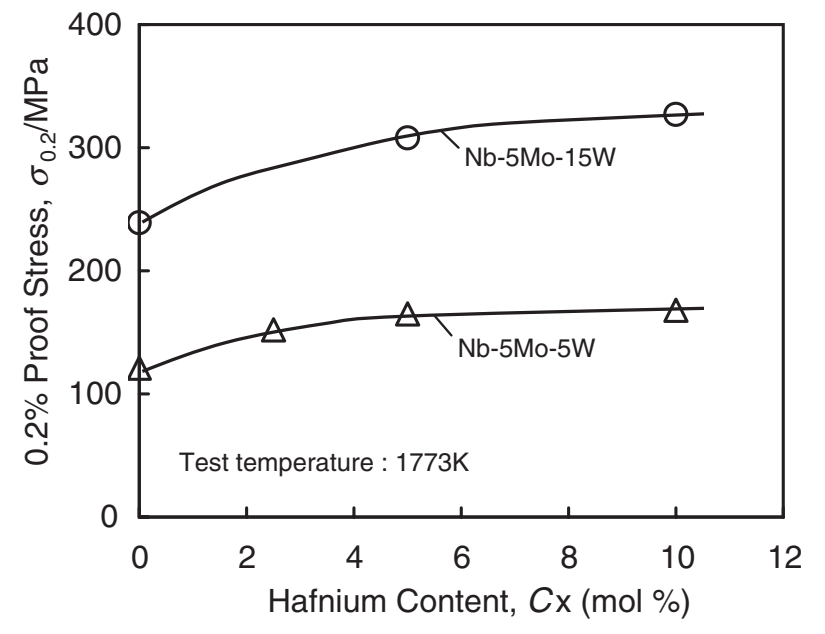

Fig. 3 Effect of hafnium addition on the $0.2 \%$ proof stress for $\mathrm{Nb}-5 \mathrm{Mo}-5 \mathrm{~W}$ and $-15 \mathrm{~W}$ alloys at $1773 \mathrm{~K}$. (On adding hafnium,the same mol\% of carbon was also added).
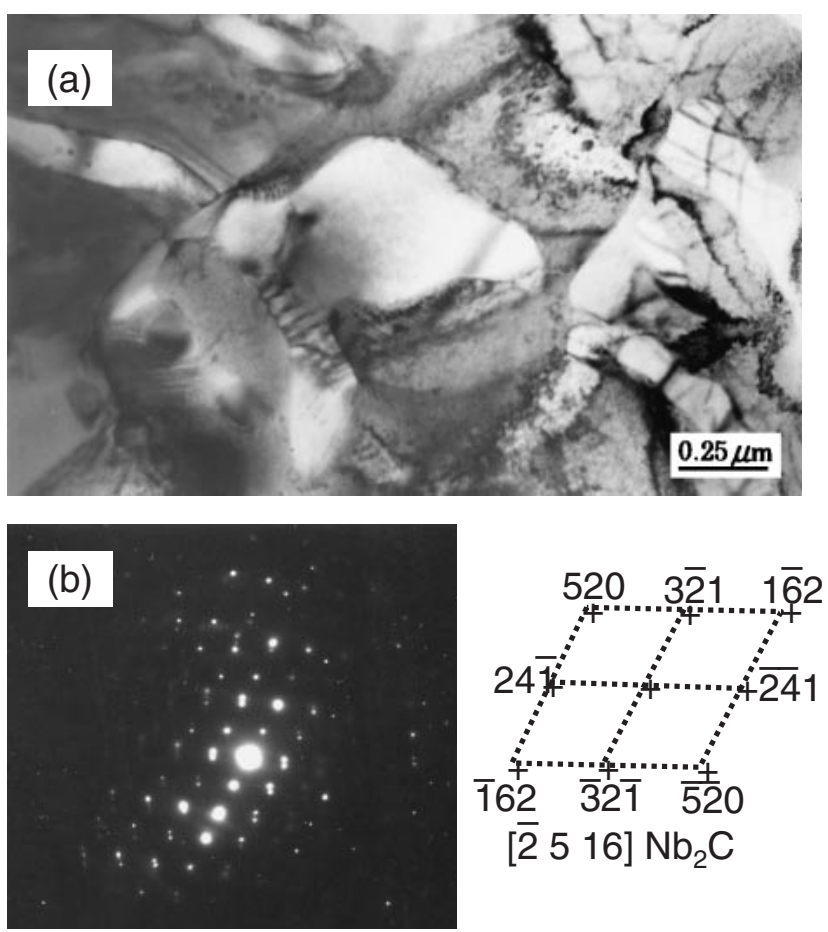

Fig. 4 The TEM micrograph (a) and diffraction pattern of $\mathrm{Nb}_{2} \mathrm{C}$ carbide with [ $\overline{2} 516]$ zone axis (b) at the center of (a) through $0.5 \mu \mathrm{m}$ selected area aperture for $\mathrm{Nb}-5 \mathrm{Mo}-15 \mathrm{~W}-5 \mathrm{Hf}$ alloy annealed at $2073 \mathrm{~K}$ for $48 \mathrm{~h}$ followed by furnace cooling to room temperature.

value by $5 \mathrm{Hf}$ addition. TEM and EDS observations on $\mathrm{Nb}$ 5Mo-15W-5Hf alloy, as shown in Fig. 4, revealed that $\mathrm{Nb}_{2} \mathrm{C}$ carbide appears in the granular type $(\sim 0.65 \mu \mathrm{m})$ and coarse rod-like forms. However, neither detectable hafnium substitution for some of niobium in $\mathrm{Nb}_{2} \mathrm{C}$ nor visible formation of hafnium carbide, $\mathrm{HfC}$, were found. To evaluate which is more dominant as the strengthening mechanism between solid-solution hardening and $\mathrm{Nb}_{2} \mathrm{C}$ dispersion strengthening, Orowan stress, $\sigma_{\text {or }}$, was estimated according to eq. 2;

$$
\sigma_{\text {or }}=0.8 \mathrm{MGb} / \lambda
$$

where $\mathrm{M}$ is the Taylor factor $(=3), \mathrm{G}$ is the shear modulus ( $\mathrm{G}$ at $1773 \mathrm{~K}$ is $108.4 \mathrm{GPa}), \mathrm{b}$ is Burgers vector $(=0.28 \mathrm{~nm})$ and 


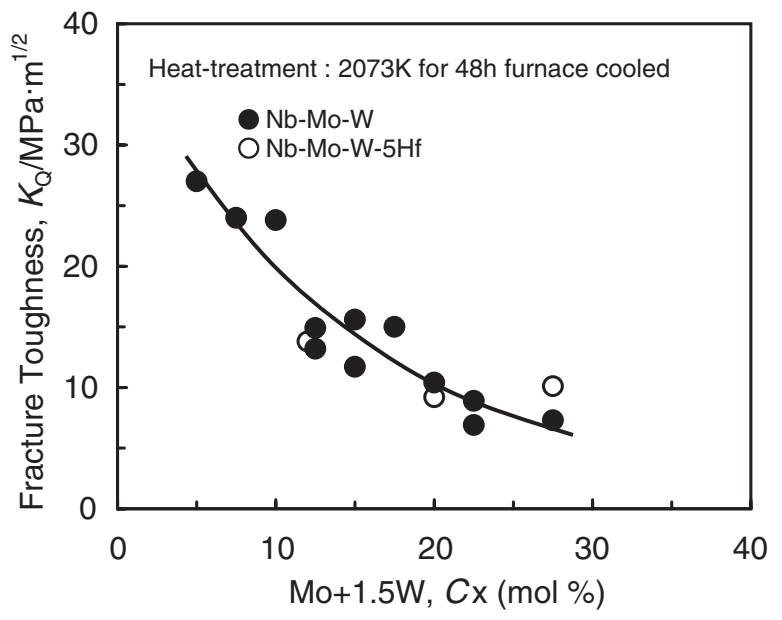

Fig. 5 Fracture toughness, $K_{\mathrm{Q}}$, plotted against $(\mathrm{Mo}+1.5 \mathrm{~W})$ content at room temperature for the solid-solution alloys.

$\lambda$ is the average spacing of the $\mathrm{Nb}_{2} \mathrm{C}$ obstacles $(=581 \mathrm{~nm})$. The obtained Orowan stress, $\sigma_{\text {or }}$, for Nb-5Mo-10W-5Hf alloy is $45 \mathrm{MPa}$, which is at most $16 \%$ of the $0.2 \%$ proof stress. This result indicates that the solid-solution hardening, which is advantageous from the viewpoint of long-term stability, substantially supports the high temperature strength of the Nb-based alloys at $1773 \mathrm{~K}$.

Figure 5 shows the relationship between room temperature fracture toughness, $K_{\mathrm{Q}}$, and $(\mathrm{Mo}+1.5 \mathrm{~W})$ content. The $K_{\mathrm{Q}}$ tend to decrease with increasing $(\mathrm{Mo}+1.5 \mathrm{~W})$ content. It is notable from Figs. 3 and 5 that by adding $5 \mathrm{Hf}-5 \mathrm{C}$ to $\mathrm{Nb}-5 \mathrm{Mo}-$ $15 \mathrm{~W}$ alloy the $K_{\mathrm{Q}}$ value increased from 7.3 to $10.1 \mathrm{MPa} \cdot \mathrm{m}^{1 / 2}$, while the $0.2 \%$ proof stress increased from 239 to $308 \mathrm{MPa}$. Such the enhancement both in strength and ductility by $5 \mathrm{Hf}-$ $5 \mathrm{C}$ addition is considered to be due to the restraint of intergranular fracture. ${ }^{6,8)}$

From the above results, there were two types of ductile-tobrittle transition behavior in Nb-Mo-W alloys at $1773 \mathrm{~K}$. One is observed in compression when $(\mathrm{Mo}+1.5 \mathrm{~W})$ content exceeds $32.5 \%$ (Fig. 2), and the other reported in tension when molybdenum content is above 15\%.6) Alloy additions over these critical contents cause a change in fracture behavior from transgranular type to intergranular type accompanying the decrease in increasing degree of $0.2 \%$ proof stress observed in compression on $\mathrm{Nb}-25 \sim 35 \mathrm{Mo}-$ $5 \sim 15 \mathrm{~W}$ alloys with $(\mathrm{Mo}+1.5 \mathrm{~W})$ content over $32.5 \%$ (Fig. 2), and a significant loss of the strength in tension with a preyield fracture for $\mathrm{Nb}-0 \sim 35 \mathrm{Mo}-5 \mathrm{~W}$ alloys with above $15 \%$ Mo. ${ }^{6}$ In Fig. 6, the pertinent compositional range is presented, where the two ductile-to-brittle transition boundaries are shown in the Nb-Mo-W ternary alloy diagram together with iso-strength lines of 100, 200 and $300 \mathrm{MPa}$ levels at $1773 \mathrm{~K}$. The transition boundary for Nb-25 35Mo$5 \sim 15 \mathrm{~W}$ alloys is considered to exist between the two alloys with the $(\mathrm{Mo}+1.5 \mathrm{~W})$ contents of $32.5 \%$ and $40.0 \%$. Because the value of $32.5 \%$ represents the maximum $(\mathrm{Mo}+1.5 \mathrm{~W})$ content where the predominant transgranular fracture mode was observed and the value $40.0 \%$ the minimum $(\mathrm{Mo}+1.5 \mathrm{~W})$ content where the predominant intergranular fracture mode was observed. So the compositional boundary here was assumed to be $33.5 \%$ which corresponds to the iso-strength

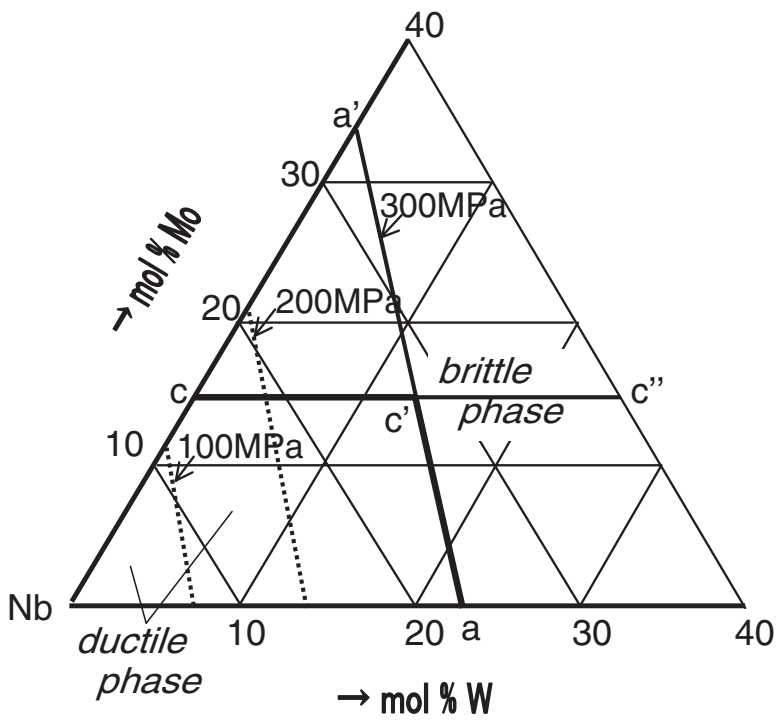

Fig. 6 Ductile-to-brittle transition boundaries $\left(a-a^{\prime}\right)$ for compression and $\left(\mathrm{c}-\mathrm{c}^{\prime}\right)$ for tension ${ }^{6)}$ of the Nb-Mo-W solid-solution alloys together with $0.2 \%$ proof strength levels of 100,200 and $300 \mathrm{MPa}$ at $1773 \mathrm{~K}$.

$$
\left(\begin{array}{c}
\mathrm{a}-\mathrm{a}^{\prime}: \% \mathrm{Mo}+1.5 \times \% \mathrm{~W}=33.5 \% \\
\mathrm{c}-\mathrm{c}^{\prime}: 15 \% \text { Mo with }(\mathrm{Nb}+\mathrm{W}) \text { of } 85 \%
\end{array}\right)
$$

line of $300 \mathrm{MPa}$ at $1773 \mathrm{~K}$ and is very close to the above alloy content. A good combination of strength and ductility is present within the compositional region surrounded by a-c' $\mathrm{c}^{\prime}-\mathrm{c}-$ $\mathrm{Nb}$ corner.

\subsection{Nb-Mo-W solid-solution/ $\mathrm{Nb}_{5} \mathrm{Si}_{3}$ silicide composite alloys}

The results in the previous section show that the Nb-Mo-W solid-solution alloys do not meet the strength requirement ( $\geqq 450 \mathrm{MPa}$ at $1773 \mathrm{~K}$ ). Therefore, we have tried to explore alloys with higher strength than Nb-Mo-W alloys by utilizing intermetallic compound $\mathrm{Nb}$-silicide, ${ }^{9}{ }^{9} \alpha \mathrm{Nb}_{5} \mathrm{Si}_{3}$, which was reported to exhibit the compressive fracture strength of $\sim 670 \mathrm{MPa}$ at $1773 \mathrm{~K}$, but without appreciable ductility at $1473-1673 \mathrm{~K}^{10)}$ before general yielding in tension.

Figure 7 shows the mechanical properties for $\mathrm{Nb}-0 \sim 20 \mathrm{Si}-$ $x \mathrm{Mo}-x \mathrm{~W}$ quaternary alloys in compression as a function of

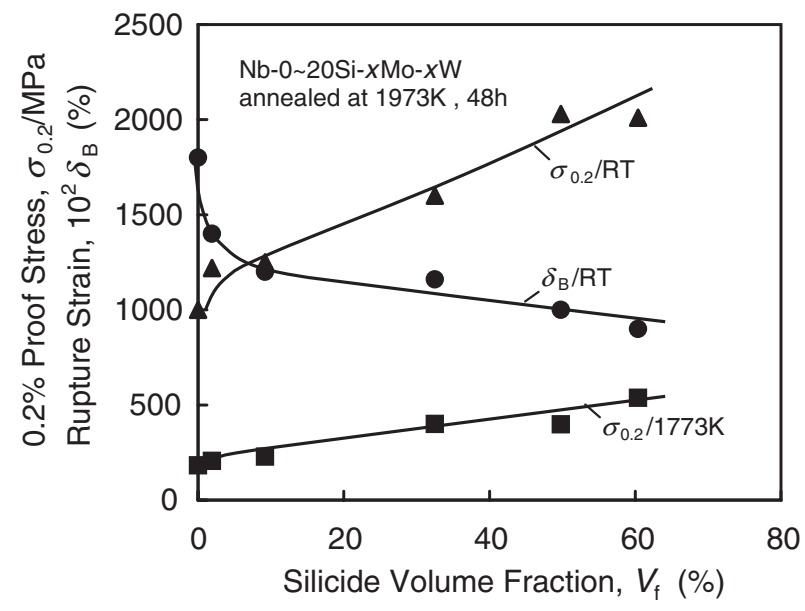

Fig. 7 Mechanical properties in compression for Nb-0 20Si- $x \mathrm{Mo}-x \mathrm{~W}$ quaternary alloys as a function of silicon content, where the composition of $\mathrm{Nb}$ solid-solution are designed to be the same as $\mathrm{Nb}-15 \mathrm{Mo}-15 \mathrm{~W}$. 
volume fraction of silicide. The volume fraction of silicide, $V_{\mathrm{f}}$, was reported to linearly increases with silicon content as $V_{\mathrm{f}}=3.085 \times(\% \mathrm{Si}) .{ }^{9)}$ In Fig. 7, chemical compositions of $\mathrm{Nb}$ solid-solution were designed to keep equal to $\mathrm{Nb}-15 \mathrm{Mo}-$ $15 \mathrm{~W} .{ }^{9)}$ The results of Fig. 7 exhibit that $0.2 \%$ proof stress both at room temperature and $1773 \mathrm{~K}$ increased with increasing silicide volume fraction, whereas rupture strain rapidly decreased with silicide content up to $9 \mathrm{vol} \%$, and then gradually decreased, to lesser extent, with further increase in silicide volume fraction. The target strength of $450 \mathrm{MPa}$ at $1773 \mathrm{~K}$ is obtained with $48.6 \mathrm{vol} \%$ silicide i.e. $15.8 \%$ silicon addition, and the microstructures reveal two consituent phases consisting of $50 \mathrm{vol} \% \alpha \mathrm{Nb}_{5} \mathrm{Si}_{3}$ (hereafter denoted as $\mathrm{Nb}_{5} \mathrm{Si}_{3}$ ) and 50 vol\% $\mathrm{Nb}$ solid-solution. As for $\mathrm{Nb}-\mathrm{Si}$ binary alloy, previous work showed that the microstructures exhibit composite-like configurations ${ }^{11)}$ of $(\mathrm{Nb}$ phase + $\mathrm{Nb}_{5} \mathrm{Si}_{3}$ ) two phases which are thermochemically and morphologically stable, at least, up to $1773 \mathrm{~K}$ for $100 \mathrm{~h}^{12)}$ Furthermore, considering the eutectic reaction to occur at $18.7 \% \mathrm{Si}$ in $\mathrm{Nb}-\mathrm{Si}$ alloy, silicon addition should be limited below $18.7 \%$ because the primary and eutectic $\mathrm{Nb}$ phases are expected to act as a so-called plasticizer in order to hold ductility.

Figure 8 shows a typical microstructure of Nb-16Si-10Mo$15 \mathrm{~W}$ alloy annealed at $1973 \mathrm{~K}$ for $48 \mathrm{~h}$. The micrograph indicates that the overall equilibrium microstructure could be viewed as large dendritically formed primary and small eutectically formed $\mathrm{Nb}$ solid-solutions particles distributed in the continuous $\mathrm{Nb}_{5} \mathrm{Si}_{3}$ silicide matrix. The chemical compositions of constituent phases are presented in Table $1 .^{9)}$ The XRD examinations revealed that the lattice parameters of $\mathrm{Nb}_{5} \mathrm{Si}_{3}$ were almost constant with the change in molybdenum and tungsten content, implying very little alloying potential of these elements into $\mathrm{Nb}_{5} \mathrm{Si}_{3}$. Whereas, molybdenum and

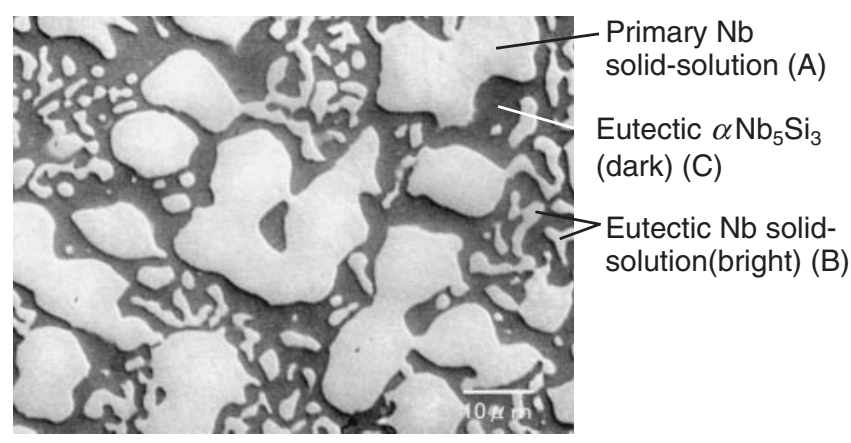

Fig. 8 SEM micrograph of Nb-16Si-10Mo-15W alloy annealed at $1973 \mathrm{~K}$ for $48 \mathrm{~h}$. Large dendritic primary $\mathrm{Nb}$ solid-solutions (A) and small eutectic $\mathrm{Nb}$ solid-solutions (B) embedded in dark eutectic $\alpha \mathrm{Nb}_{5} \mathrm{Si}_{3}$ matrix (C). tungsten are enriched in the $\mathrm{Nb}$ solid-solutions, and the ratios of these alloying contents in the $\mathrm{Nb}$ solid-solution to those in nominal alloy composition are $1.4 \sim 1.5$ for molybdenum and $1.5 \sim 1.7$ for tungsten. The silicon content is only $0.4 \sim 0.6 \%$ in the solid-solution, while it is $37.4 \sim 38.5 \%$ in $\mathrm{Nb}_{5} \mathrm{Si}_{3}$.

The relationship between $0.2 \%$ proof stress at $1773 \mathrm{~K}$ and $(\mathrm{Mo}+1.5 \mathrm{~W})$ contents for Nb-16Si-Mo-W alloys is shown in Fig. 9, where a linear relationship is clearly observed. The increasing rate of $0.2 \%$ proof stress with respect to alloy content for $\mathrm{Nb}-16 \mathrm{Si}-\mathrm{Mo}-\mathrm{W}$ alloys was almost 2.5 times higher than that of $\mathrm{Nb}-\mathrm{Mo}-\mathrm{W}$ alloys probably due to the segregation of molybdenum and tungsten in $\mathrm{Nb}$ solidsolution phase. Figure 9 also shows that the target strength of $450 \mathrm{MPa}$ at $1773 \mathrm{~K}$ is achieved by the addition of (Mo+1.5W) content above $16 \%$.

If the rule of mixtures, ${ }^{13)}$ which is generally known as to the strength of fiber reinforced ceramic matrix composite material, is valid in the present $\mathrm{Nbss} / \mathrm{Nb}_{5} \mathrm{Si}_{3}$ composite alloy, the strength, $\sigma_{\text {comp }}$, may be expressed as

$$
\sigma_{\text {comp }}=V_{\mathrm{f}} \sigma_{\text {silicide }}+\left(1-V_{\mathrm{f}}\right) \sigma_{\mathrm{ss}}
$$

where $V_{\mathrm{f}}$ is the volume fraction of $\mathrm{Nb}_{5} \mathrm{Si}_{3}, \sigma_{\text {silicide }}$ is the strength of $\mathrm{Nb}_{5} \mathrm{Si}_{3}$ at $1773 \mathrm{~K}$, which has been reported to be $\sim 670 \mathrm{MPa}^{14)}$ as the compressive fracture strength, and $\sigma_{\mathrm{ss}}$ is the strength of $\mathrm{Nb}$ solid-solution phase at $1773 \mathrm{~K}$ which is obtained as the $0.2 \%$ proof stress corresponding to 1.5 times nominal $(\mathrm{Mo}+1.5 \mathrm{~W})$ content in $\mathrm{Nb}-\mathrm{Mo}-\mathrm{W}$ solid-solution

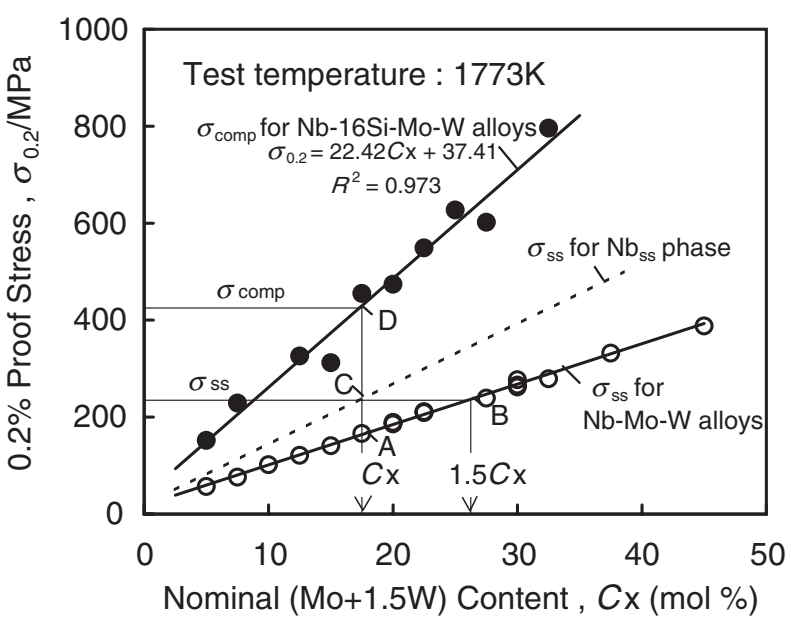

Fig. 9 Plots of compressive $0.2 \%$ proof stress, $\sigma_{0.2}$, as a function of $(\mathrm{Mo}+1.5 \mathrm{~W})$ content at $1773 \mathrm{~K}$ for $\mathrm{Nb}-16 \mathrm{Si}-\mathrm{Mo}-\mathrm{W}$ alloys together with those of $\mathrm{Nb}-\mathrm{Mo}-\mathrm{W}$ alloys for reference. Schematic representation of strengthening mechanism is also shown, where $\sigma_{\mathrm{ss}}$ is the assumed $0.2 \%$ proof stress for $\mathrm{Nb}$ solid-solution, Nbss, as a constituent phase and $\sigma_{\text {comp }}$ is that for $\mathrm{Nbss} / \mathrm{Nb}_{5} \mathrm{Si}_{3}$ composite alloy.

Table 1 Chemical compositions of the constituent phases in Nb-16Si-Mo-W alloys annealed at $1973 \mathrm{~K}$ for $48 \mathrm{~h}$.

\begin{tabular}{|c|c|c|c|}
\hline \multirow{2}{*}{ Alloys } & \multirow{2}{*}{$\begin{array}{c}\text { Constituent } \\
\text { phases }\end{array}$} & \multicolumn{2}{|c|}{ Phase compositions } \\
\hline & & $\alpha \mathrm{Nb}_{5} \mathrm{Si}_{3}$ & Nbss \\
\hline Nb-16Si-10Mo-5W & $\mathrm{Nbss}+\alpha \mathrm{Nb}_{5} \mathrm{Si}_{3}$ & Nb-1Mo-0.4W-37.4Si & $\mathrm{Nb}-14.8 \mathrm{Mo}-7.4 \mathrm{~W}-0.6 \mathrm{Si}$ \\
\hline Nb-16Si-10Mo-15W & $\mathrm{Nbss}+\alpha \mathrm{Nb}_{5} \mathrm{Si}_{3}$ & $\mathrm{Nb}-1.5 \mathrm{Mo}-0.8 \mathrm{~W}-37.5 \mathrm{Si}$ & $\mathrm{Nb}-14.8 \mathrm{Mo}-25.3 \mathrm{~W}-0.5 \mathrm{Si}$ \\
\hline Nb-16Si-5Mo-15W & $\mathrm{Nbss}+\alpha \mathrm{Nb}_{5} \mathrm{Si}_{3}$ & $\mathrm{Nb}-0.6 \mathrm{Mo}-0.9 \mathrm{~W}-37.8 \mathrm{Si}$ & $\mathrm{Nb}-6.7 \mathrm{Mo}-25.7 \mathrm{~W}-0.4 \mathrm{Si}$ \\
\hline
\end{tabular}


alloy as in Fig. 9. The coefficient, 1.5, is the mean ratio of the molybdenum and tungsten contents in $\mathrm{Nb}$ solid-solution phase to those as nominal contents (Table 1). In case of $C \mathrm{x}$ equal to $17 \%$, for example, where the measured $\sigma_{\text {comp }}$ for $\mathrm{Nb}$ $16 \mathrm{Si}-\mathrm{Mo}-\mathrm{W}$ alloy is $455 \mathrm{MPa}$, using $V_{\mathrm{f}}=0.5, \sigma_{\text {silicide }}=$ $\sim 670 \mathrm{MPa}$, and $\sigma_{\text {ss }}$ for Nbss phase (at point C) is $235 \mathrm{MPa}$ which corresponds to $\sigma_{\mathrm{ss}}$ for Nb-Mo-W alloys at $1.5 \mathrm{Cx}$, eq. (3) yields $\sigma_{\text {comp }}$ for a Nb-16Si-Mo-W alloy with nominal (Mo+1.5W) content of $17 \%$ to be $\sim 453 \mathrm{MPa}$ which is regarded to be comparable with the actual value for $\sigma_{\text {comp }}$ being $455 \mathrm{MPa}$. Such an agreement is observed only in the $C \mathrm{x}$ range from $15 \%$ to $20 \%$. The measured $0.2 \%$ proof stress, $\sigma_{\text {comp }}$, is fairly smaller than the predicted value from eq. (3) when $C \mathrm{x}$ is below $15 \%$, and however the measured value is larger than the predicted value when $C x$ is above $20 \%$. These results indicate that the rule of mixtures is not valid in the wide range of $C \mathrm{x}$ value for the present $\mathrm{Nb}$ solid-solution/ $\mathrm{Nb}_{5} \mathrm{Si}_{3}$-reinforced composite alloys, wherein the strength and ductility levels are greatly different between the two constituent phases unlike the $\mathrm{SiC}$ fiber reinforced $\mathrm{SiC}$ matrix $\mathrm{SiC} / \mathrm{SiC}$ composites consisting of the same constituent material $(\mathrm{SiC})$. The $0.2 \%$ proof stress, $\sigma_{\text {comp }}$, for $\mathrm{Nb}-16 \mathrm{Si}$ Mo-W alloys is then given by a linear regression analysis as

$$
\sigma_{\text {comp }} / \mathrm{MPa}=22.42(\mathrm{Mo}+1.5 \mathrm{~W})+37.4, \quad R^{2}=0.973
$$

Figure 10 shows the room temperature fracture toughness, $K_{\mathrm{Q}}$, plotted against $(\mathrm{Mo}+1.5 \mathrm{~W})$ content for $\mathrm{Nb}-16 \mathrm{Si}-\mathrm{Mo}-\mathrm{W}$ and $\mathrm{Nb}-16 \mathrm{Si}-\mathrm{Mo}-\mathrm{W}-5 \sim 10 \mathrm{Hf}$ alloys. The $K_{\mathrm{Q}}$ values for $\mathrm{Nb}$ Mo-W alloys are also shown for comparison. The $K_{\mathrm{Q}}$ values for $\mathrm{Nb}-16 \mathrm{Si}-\mathrm{Mo}-\mathrm{W}$ alloys, including alloys modified with 5Hf-5C addition, tended to decrease rather slowly with increasing $(\mathrm{Mo}+1.5 \mathrm{~W})$ content comparing to those for $\mathrm{Nb}$ Mo-W alloys. The $K_{\mathrm{Q}}$ values for Nb-16Si-5Mo-5 15W-5Hf alloys with the $(\mathrm{Mo}+1.5 \mathrm{~W})$ content of $12.5 \sim 27.5 \%$ slightly decreased with tungsten content from $8.5 \mathrm{MPa} \cdot \mathrm{m}^{1 / 2}$ to $7.9 \mathrm{MPa} \cdot \mathrm{m}^{1 / 2}$, while $0.2 \%$ proof stresses at $1773 \mathrm{~K}$ greatly increased from $257 \mathrm{MPa}$ to $465 \mathrm{MPa}$, satisfying the target strength. Furthermore, the addition of $5 \mathrm{Hf}-5 \mathrm{C}$ to $\mathrm{Nb}-16 \mathrm{Si}$ -

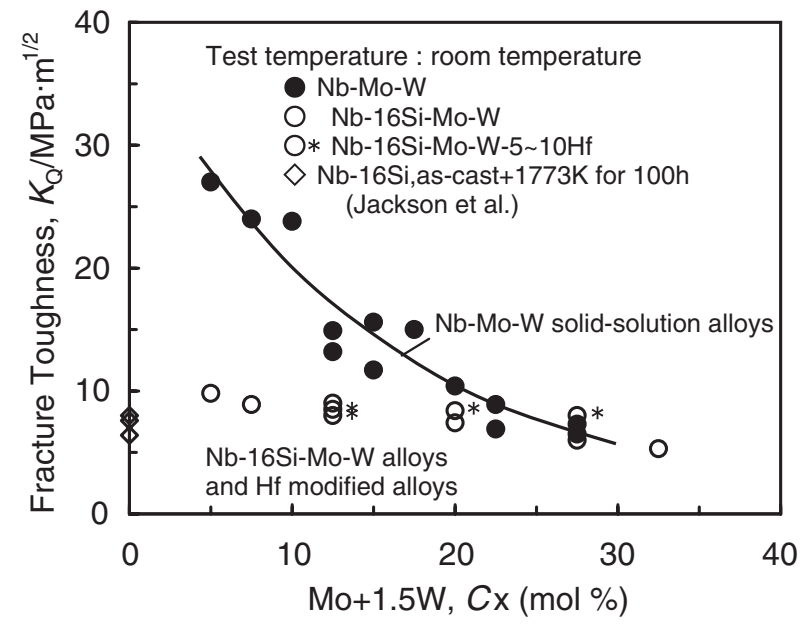

Fig. 10 Fracture toughness, $K_{\mathrm{Q}}$, at room temperature for Nb-16Si-Mo-W and $\mathrm{Nb}-16 \mathrm{Si}-\mathrm{Mo}-\mathrm{W}-5 \sim 10 \mathrm{Hf}$ alloys. The $K_{\mathrm{Q}}$ values for Nb-Mo-W alloys are also plotted for comparison.
$5 \mathrm{Mo}-10 \mathrm{~W}$ and $-15 \mathrm{~W}$ alloys results in the increase in $K_{\mathrm{Q}}$ value of 1.0 and $1.9 \mathrm{MPa} \cdot \mathrm{m}^{1 / 2}$, respectively. Kim et al., ${ }^{5)}$ have reported that the beneficial effect of $5 \mathrm{Hf}-5 \mathrm{C}$ addition could result from the existence of $\mathrm{Nb}$ carbide dispersoids as well as $\mathrm{Nb}_{5} \mathrm{Si}_{3}$ phases, which causes the crack deflection and branching through the interphase-debonding between $\mathrm{Nb}$ solid-solution and $\mathrm{Nb}$ carbide dispersoids or $\mathrm{Nb}_{5} \mathrm{Si}_{3}$ and $\mathrm{Nb}$ solid-solution. ${ }^{5)}$ It is also noted that the $\mathrm{Nb}$ carbide, which some of niobium was replaced by hafnium and confirmed by TEM and EDS to be $(\mathrm{Nb}, \mathrm{Hf})_{2} \mathrm{C}$, became smaller in size by the addition of 5 Hf-5C. ${ }^{5,8)}$

\subsection{High temperature creep strength}

$0.2 \%$ proof stress at $1773 \mathrm{~K}$ for the silicide-reinforced $\mathrm{Nb}$ $16 \mathrm{Si}-5 \mathrm{Mo}-5 \sim 15 \mathrm{~W}-5 \mathrm{Hf}$ alloys, especially for the alloys with $15 \%$ tungsten exceeds the target strength. Accordingly, the high temperature creep and creep rupture tests have been carried out mainly on the silicide-reinforced alloys to clarify the effects of chemical compositions, and to select the most possible candidate alloy.

The typical creep curves at $1773 \mathrm{~K}$ are shown in Fig. 11 along with some of the solid-solution hardened alloys for comparison. The applied stresses are $100 \mathrm{MPa}$ for the silicide-reinforced alloys and the half of that for the solidsolution alloys depending on the strength levels of the alloys. Figure 11 shows that better creep resistance was observed at Nb-16Si-5Mo-15W-5Hf alloy.

Figure 12 represents plots of the normalized minimum creep rate against the normalized stress for several Nb-Mo-W solid-solution alloys, Nb-16Si-Mo-W silicide-reinforced alloys and intermetallic $\mathrm{Nb}_{5} \mathrm{Si}_{3}$, where the values of activation energy for minimum creep rate, $Q \mathrm{c}$, were $655 \mathrm{~kJ} / \mathrm{mol}$ for $\mathrm{Nb}$ Mo-W alloys, ${ }^{15)} 675 \mathrm{~kJ} / \mathrm{mol}$ for $\mathrm{Nb}-16 \mathrm{Si}-\mathrm{Mo}-\mathrm{W}$ alloys, ${ }^{16)}$ and $234 \mathrm{~kJ} / \mathrm{mol}$ for $\mathrm{Nb}_{5} \mathrm{Si}_{3},{ }^{10)}$ respectively. Figure 12 indicates that the creep resistances are improved by increasing molybdenum and tungsten content i.e. $(\mathrm{Mo}+1.5 \mathrm{~W})$ content for the solid-solution alloys, and also the silicide-reinforced alloy with $15 \% \mathrm{~W}$ exhibits a higher creep resistance than the solid-solution alloys. $\mathrm{Nb}_{5} \mathrm{Si}_{3}$ shows the lowest creep rate, but it is not applicable to structural uses because of its poor

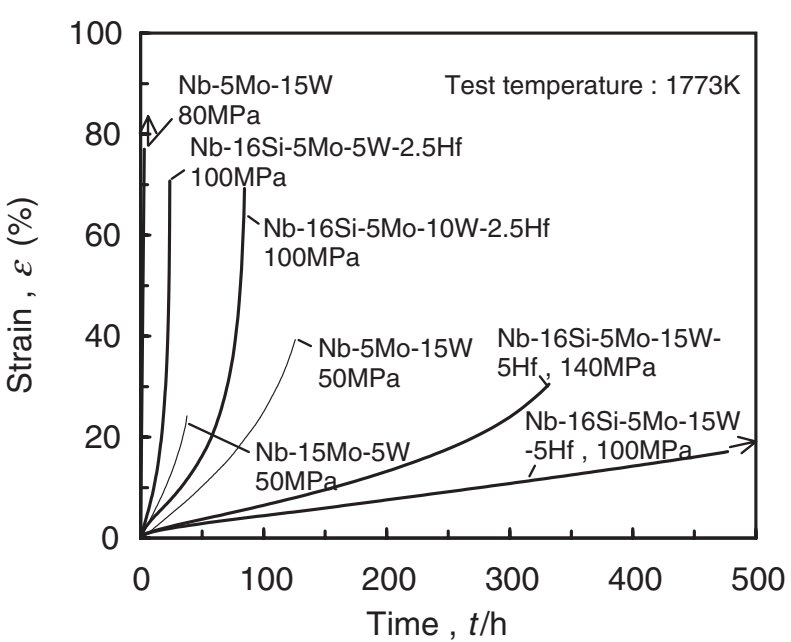

Fig. 11 Typical tensile creep curves at $1773 \mathrm{~K}$ for $\mathrm{Nb}-\mathrm{Mo}-\mathrm{W}$ solidsolution hardened alloys and $\mathrm{Nb}-16 \mathrm{Si}-\mathrm{Mo}-\mathrm{W}$ silicide-reinforced alloys. 


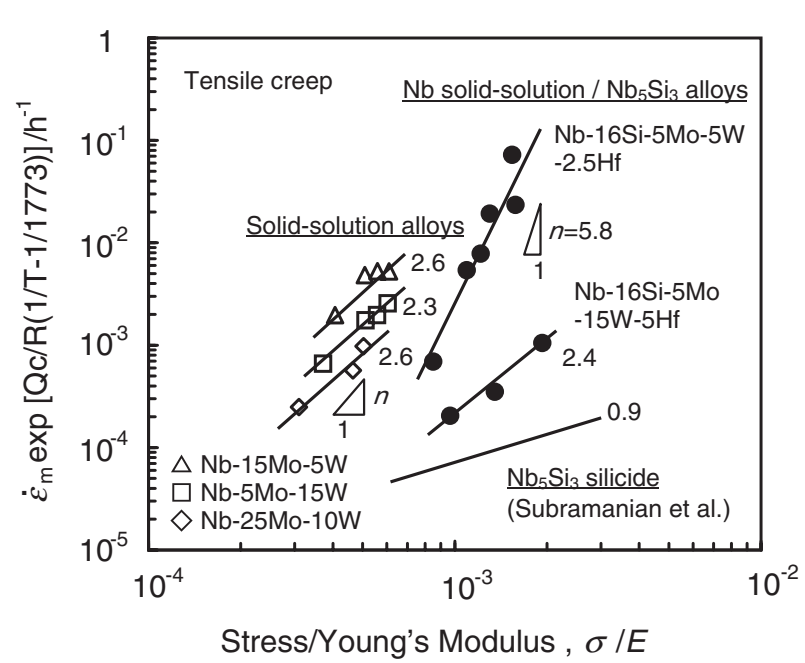

Fig. 12 Normalized minimum creep rate of several $\mathrm{Nb}$ alloys as a function of stress/Young's modulus. The creep rate is converted into that at $1773 \mathrm{~K}$ using apparent activation energy, $Q \mathrm{c}$, for minimum creep rate.

toughness and ductility.

Very little has been reported on the creep behavior of monolithic $\mathrm{Nb}_{5} \mathrm{Si}_{3} . \mathrm{Nb}_{5} \mathrm{Si}_{3}$ has the ordered tetragonal structure with 32 atoms/cell both in $\alpha \mathrm{Nb}_{5} \mathrm{Si}_{3}$ and $\beta$ $\mathrm{Nb}_{5} \mathrm{Si}_{3},{ }^{17)}$ and has been considered that the dislocation creep is unlikely to occur, because large Burgers vector and complex dislocation core structure are expected in this monolithic intermetallic. Instead, based on a stress exponent $n$ of $\sim 1$, and the activation energy for creep, $Q$ c, it, has been suggested that creep of $\mathrm{Nb}_{5} \mathrm{Si}_{3}$ probably occurs by the Nabarro-Herring mechanism.

The normalized minimum creep rate, $\dot{\varepsilon}_{\mathrm{m}}$, for $\mathrm{Nb}-16 \mathrm{Si}$ $5 \mathrm{Mo}-15 \mathrm{~W}-5 \mathrm{Hf}$ silicide-reinforced alloy as the most possible candidate material can be described in the form of power relation by

$$
\dot{\varepsilon}_{\mathrm{m}}=1.922 \times 10^{23} \times(\sigma / E)^{2.4} \exp \left(-8.11 \times 10^{4} / T\right)
$$

where $E$ is the Young's modulus in MPa, $\sigma$ is the applied stress in $\mathrm{MPa}$, and $T$ is the test temperature in $\mathrm{K}$. The stress exponent, $n(=2.4)$, and the activation energy, $Q \mathrm{c}(=675 \mathrm{~kJ} /$ $\mathrm{mol})^{16)}$ are used in calculating eq. (5). Considering the $Q \mathrm{c}$ value of this alloy and the reported values of activation energy for diffusion of molybdenum and tungsten in niobium, $511 \mathrm{~kJ} / \mathrm{mol}$ and $653 \mathrm{~kJ} / \mathrm{mol}$, respectively, ${ }^{18)}$ it seems that the creep process in this alloy is rate-controlled by the diffusion of tungsten in the $\mathrm{Nb}$ solid-solution.

Figure 13 shows plots of time-to-rupture, $t_{\mathrm{r}}$, against stress, $\sigma$, at $1773 \mathrm{~K}$. It is evidently shown that the rupture time, $t_{\mathrm{r}}$, is simply given by $t_{\mathrm{r}}=\mathrm{k} \sigma^{\mathrm{m}}$, where $\mathrm{k}$ is the constant and $m$ is the stress exponent for rupture, and also $t_{\mathrm{r}}$ becomes longer with increasing tungsten and hafnium content for $\mathrm{Nb}-16 \mathrm{Si}$ $5 \mathrm{Mo}-\mathrm{W}-\mathrm{Hf}$ alloys, and also the substitution of silicon or molybdenum for tungsten is not valid to improve the creep rupture strengths as observed in Nb-20Si-Mo alloys. These results lead to conclude that the tungsten addition is significantly effective to enhance the high temperature creep strength, but the addition should be controlled below the critical $(\mathrm{Mo}+1.5 \mathrm{~W})$ content with respect to the ductile-to-

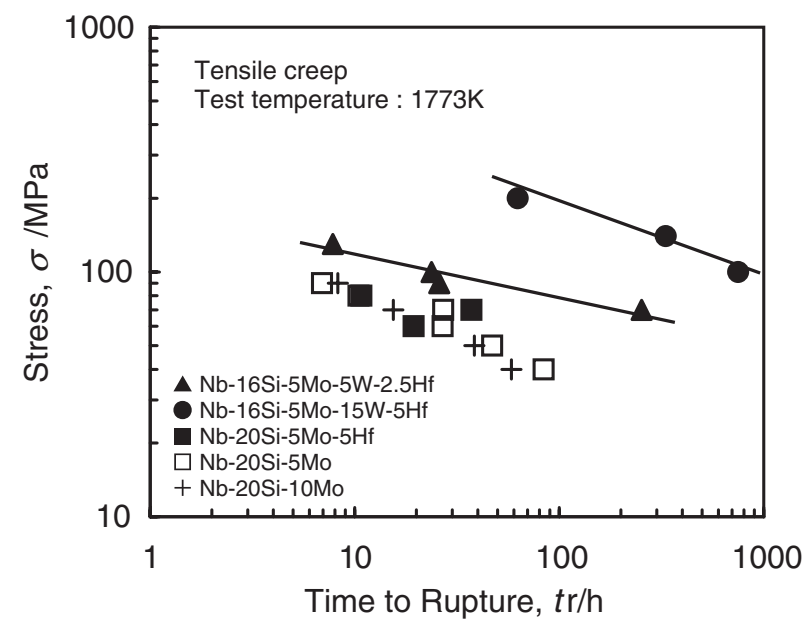

Fig. 13 Time-to-rupture as a function of stress for several silicidereinforced alloys at $1773 \mathrm{~K}$ (solid symbols denote alloys with 2.5 or $5.0 \%$ Hf added).

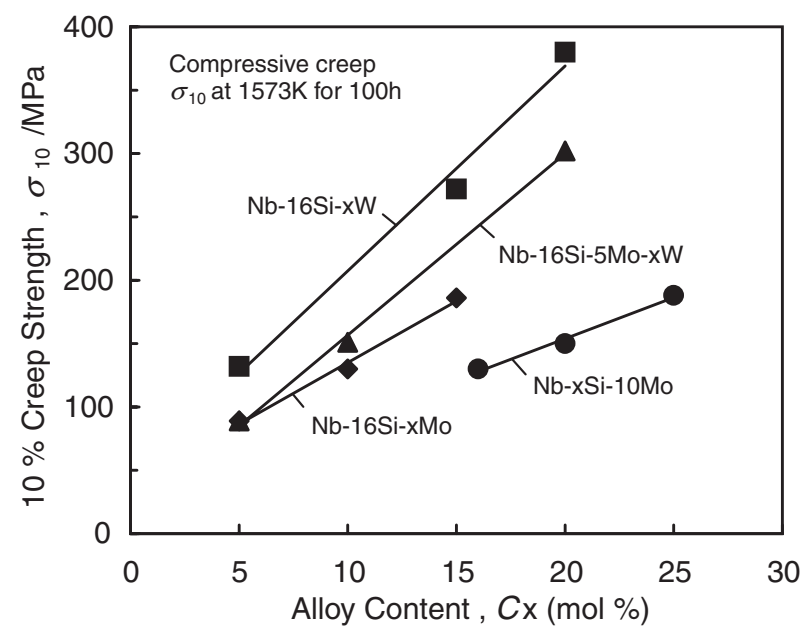

Fig. $1410 \%$ creep strength $\sigma_{10}$ at $1573 \mathrm{~K}$ for $100 \mathrm{~h}$ in compressive creep tests plotted against silicon, molybdenum and tungsten contents for silicide-reinforcing alloys.

brittle transition, and to be optimized to a proper amount without deteriorating the fracture toughness and the ingot soundness.

The quantitative strengthening effects of silicon, molybdenum, and tungsten on the $10 \%$ creep strength in compressive creep tests for silicide-reinforced $\mathrm{Nb}-16 \mathrm{Si}-\mathrm{Mo}-\mathrm{W}$ alloys has been studied as a function of the alloy composition in the range of $5 \sim 15 \% \mathrm{Mo}, 0 \sim 20 \% \mathrm{~W}$, and $16 \sim 25 \% \mathrm{Si}$. Figure 14 shows $10 \%$ creep strength plotted against the alloy content, and indicates that the relative ratios of strengthening effect of molybdenum, silicon, and tungsten were 1: 0.65 : 1.6. The strengthening effects of these alloying elements mainly result from solid-solution hardening as to both molybdenum and tungsten, and silicide-reinforcing effect as to silicon as discussed in the previous section. These results reveal that the strengthening effect of tungsten is much greater than those of molybdenum and silicon, which was similarly observed in the tensile and compressive tests of this work. 


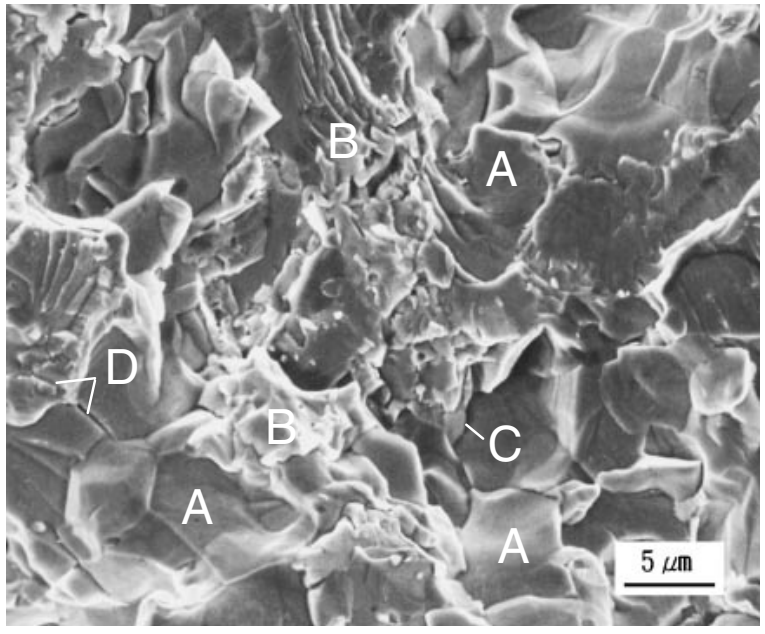

Fig. 15 SEM micrograph for Nb-16Si-5Mo-15W-5Hf alloy crept at $1773 \mathrm{~K}$ and $140 \mathrm{MPa}$ to $332 \mathrm{~h}$ with creep rupture strain of $21.3 \%$.

Fractographic observations have been conducted to examine the fracture behavior of the most possible candidate alloy, Nb-16Si-5Mo-15W-5Hf, crept at $1773 \mathrm{~K}$ and $140 \mathrm{MPa}$ to $332 \mathrm{~h}$ with an elongation after creep rupture of $21.3 \%$. Figure 15 shows a SEM micrograph of fracture surface exhibiting a number of different fracture modes which include brittle fracture of $\mathrm{Nb}_{5} \mathrm{Si}_{3}(\mathrm{~A})$, transgranular fracture with some dimples of $\mathrm{Nb}$ solid-solution (B), $\mathrm{Nb}$ solid-solution $/ \mathrm{Nb}_{5} \mathrm{Si}_{3}$ interface decohesion (C), and the crack evolving from the silicide to the adjacent $\mathrm{Nb}$ solidsolution (D). EDS analysis revealed the microstructural constituents are $\mathrm{Nb}$ solid-solution and $\mathrm{Nb}_{5} \mathrm{Si}_{3}$ phase. A large number of cracks in the $\mathrm{Nb}_{5} \mathrm{Si}_{3}$ matrix were observed to initiate at the interface. These cracks evolved into the inner part of $\mathrm{Nb}_{5} \mathrm{Si}_{3}$ phase and eventually collided with the other solid-solutions particles, resulting in the interface decohesion in some case or the solid-solution cracking as marked by $\mathrm{C}$ in Fig. 16. TEM examinations clearly reveal that a microcrack

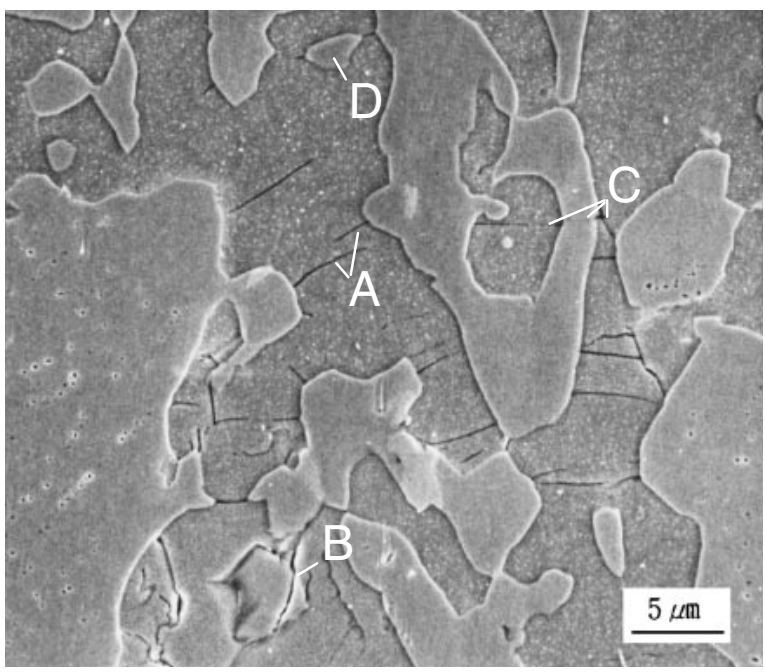

Fig. 16 BEI micrograph of longitudinal cross-section for $\mathrm{Nb}-16 \mathrm{Si}-5 \mathrm{Mo}-$ $15 \mathrm{~W}-5 \mathrm{Hf}$ alloy crept at $1773 \mathrm{~K}$ and $140 \mathrm{MPa}$ to $332 \mathrm{~h}$ with an elongation after creep rupture of $21.3 \%$. A: crack evolving into the inner part of $\mathrm{Nb}_{5} \mathrm{Si}_{3}, \mathrm{~B}$ : interface decohesion, $\mathrm{C}$ : crack penetrating through $\mathrm{Nb}$ solidsolution, D: crack-bridging.
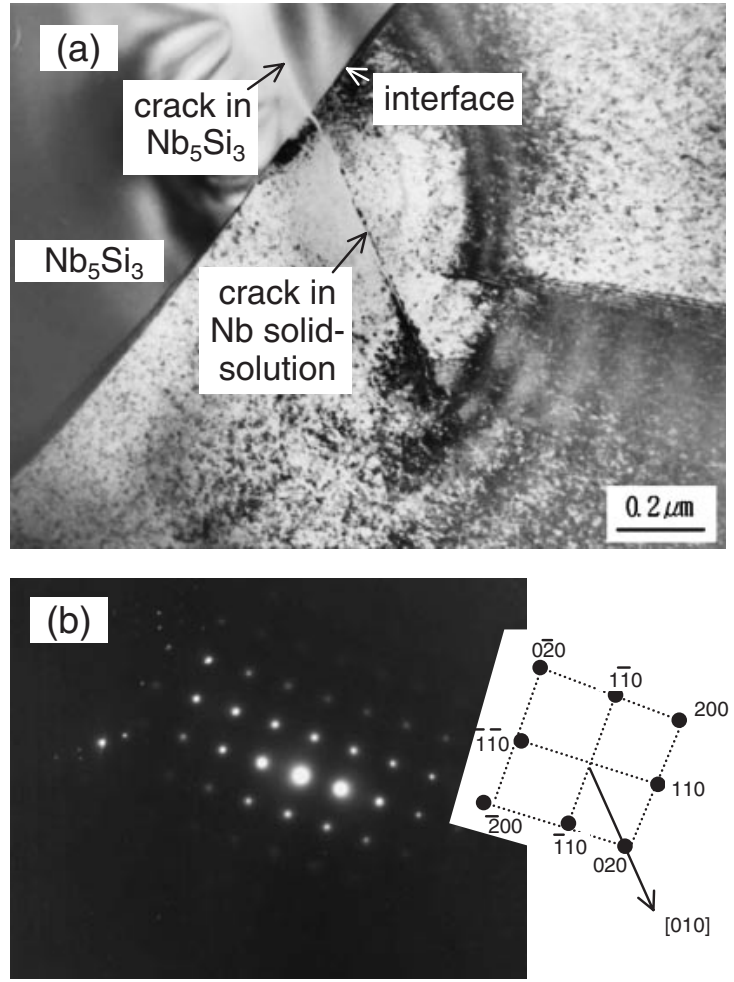

Fig. 17 Crack advancement from $\mathrm{Nb}_{5} \mathrm{Si}_{3}$ to $\mathrm{Nb}$ solid-solution through the interface observed in Nb-16Si-5Mo-15W-5Hf alloy crept at $1773 \mathrm{~K}$ and $140 \mathrm{MPa}$ to $332 \mathrm{~h}$ with an elongation after creep rupture of $21.3 \%$, (a) TEM micrograph, (b) TEM pattern of cracked $\mathrm{Nb}$ solid-solution with [001] zone axis.

formed in the $\mathrm{Nb}$ solid-solution through $\mathrm{Nbss} / \mathrm{Nb}_{5} \mathrm{Si}_{3}$ interfaces, which does not notice in BEI micrograph, was observed at the position where an advancing crack in the $\mathrm{Nb}_{5} \mathrm{Si}_{3}$ collides with the $\mathrm{Nb}$ solid-solution, as shown in Fig. 17.

Figure 18 shows the Larson-Miller plots for the Nb solidsolution alloys and the $\mathrm{Nb}_{5} \mathrm{Si}_{3}$-reinforced alloys studied in the present investigation in comparison with those for

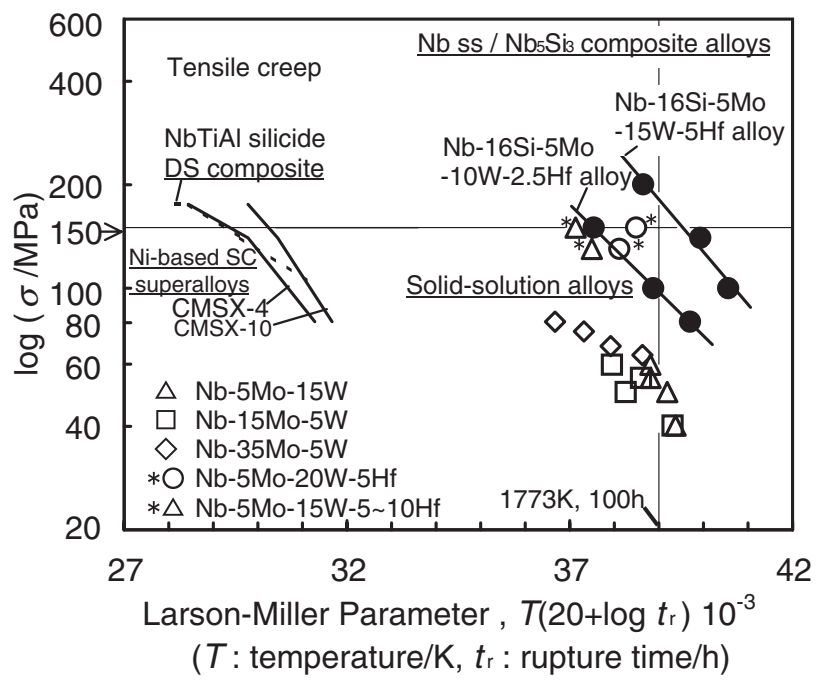

Fig. 18 Comparison of creep rupture strength of newly developed $\mathrm{Nb}$ based alloys with those of NbTiAl silicide DS composite, and second- \& third-generation Ni-based single-crystal superalloys. 
directionally-solidified(DS) NbTiAl silicide composite, ${ }^{3)}$ and second- and third-generation single crystal Ni-based superalloys. ${ }^{19)}$ The stress-rupture performance of the DS composite is similar to those of advanced single-crystal Ni-based superalloy. The Nb-Mo-W solid-solution alloys modified with Hf show significantly higher temperature capabilities than those of the referred alloys. Especially the $\mathrm{Nb}_{5} \mathrm{Si}_{3}-$ reinforced $\mathrm{Nb}-16 \mathrm{Si}-5 \mathrm{Mo}-15 \mathrm{~W}-5 \mathrm{Hf}$ alloy as a most possible candidate material demonstrates an extremely high creep rupture strength, and satisfies the target strength of $150 \mathrm{MPa}$ or above at $1773 \mathrm{~K}$ for $100 \mathrm{~h}$. When Larson-Miller parameter, $\mathrm{L}-\mathrm{MP}=T\left(20+\log t_{\mathrm{r}}\right)$, is related to stress, $\sigma$, in the form of

$$
\mathrm{L}-\mathrm{MP} \times 10^{-3}=\mathrm{k} \log \sigma+\sigma_{0}
$$

where $T$ is the temperature in $\mathrm{K}, t_{\mathrm{r}}$ is the creep rupture time in $\mathrm{h}$, and $\mathrm{k}$ and $\sigma_{0}$ are constants, Nb-16Si-5Mo-15W-5Hf alloy shows a creep rupture strength of $180 \mathrm{MPa}$ at $1773 \mathrm{~K}$ for $100 \mathrm{~h}$, and an endurance temperature of $1800 \mathrm{~K}$ at $150 \mathrm{MPa}$ for $100 \mathrm{~h}$. It should be noticeable that materials having such unprecedentedly high strength at such high temperature have not been reported before.

\section{Conclusions}

A Nb-based alloy system expecting the use for gas turbine materials at $1773 \mathrm{~K}$ was explored, focusing on the ultra-high temperature strength and room temperature fracture toughness as a function of chemical composition. The main results obtained are summarized as follows.

(1) $0.2 \%$ proof stresses of both $\mathrm{Nb}-\mathrm{Mo}-\mathrm{W}$ solid-solution alloys and $\mathrm{Nb}_{5} \mathrm{Si}_{3}$-reinforced $\mathrm{Nb}-\mathrm{Si}-\mathrm{Mo}-\mathrm{W}$ alloys with a microstructure consisting of $\mathrm{Nb}$ solid-solution and $\mathrm{Nb}_{5} \mathrm{Si}_{3}$ at $1773 \mathrm{~K}$ were found to increase linearly with $(\mathrm{Mo}+1.5 \mathrm{~W})$ content, and that of the latter alloys also increased with the volume fraction of $\mathrm{Nb}_{5} \mathrm{Si}_{3}$.

(2) Room temperature fracture toughness, $K_{\mathrm{Q}}$, of both alloy systems decreased with $(\mathrm{Mo}+1.5 \mathrm{~W})$ content, while $K_{\mathrm{Q}}$ of $\mathrm{Nb}_{5} \mathrm{Si}_{3}$-reinforced alloys decreased to lesser extent than that of $\mathrm{Nb}-\mathrm{Mo}-\mathrm{W}$ alloys. The critical $(\mathrm{Mo}+1.5 \mathrm{~W})$ content was $33.5 \mathrm{~mol} \%$ together with molybdenum content of $15 \mathrm{~mol} \%$ in $\mathrm{Nb}$ solid-solution phase for a ductile-to-brittle transition to occur, accompanying change in fracture mode and pre-yield fracture.

(3) The addition of $5 \mathrm{Hf}-5 \mathrm{C}$ to strengthen Nb-5Mo-15W alloy and $\mathrm{Nb}-16 \mathrm{Si}-5 \mathrm{Mo}-15 \mathrm{~W}$ alloy yields 2.8 and $1.9 \mathrm{MPa} \cdot \mathrm{m}^{1 / 2}$ higher room temperature fracture toughness than those of alloys without 5Hf-5C addition, respectively.

(4) $10 \%$ creep strength of Nb-Si-Mo-W alloys is enhanced by the additions of $\mathrm{Mo}, \mathrm{Si}$, and $\mathrm{W}$, where the relative ratios of the strengthening effect are to be Mo: $\mathrm{Si}: \mathrm{W}=1: 0.65: 1.6$.

(5) Excellent creep resistances and higher creep rupture strengths exhibited for $\mathrm{Nb}-16 \mathrm{Si}-5 \mathrm{Mo}-15 \mathrm{~W}-5 \mathrm{Hf}$ alloy among the Nb-based alloys studied, where the greater tungsten content gave the higher creep strength.

(6) Several fracture modes including extensive fracture of brittle $\mathrm{Nb}_{5} \mathrm{Si}_{3}$ and the resultant $\mathrm{Nbss} / \mathrm{Nb}_{5} \mathrm{Si}_{3}$ interface decohesion and cracking in Nbss were observed in creep ruptured $\mathrm{Nb}_{5} \mathrm{Si}_{3}$-reinforced $\mathrm{Nb}$-16Si-Mo-W alloys.

(7) $\mathrm{Nb}-16 \mathrm{Si}-5 \mathrm{Mo}-15 \mathrm{~W}-5 \mathrm{Hf}$ alloy as the most possible candidate alloy exhibits a $0.2 \%$ proof stress of $465 \mathrm{MPa}$, a specific strength of $52 \mathrm{MPa} / \mathrm{Mg} \cdot \mathrm{m}^{-3}$ at $1773 \mathrm{~K}$, and a creep rupture strength of $180 \mathrm{MPa}$ at $1773 \mathrm{~K}$ for $100 \mathrm{~h}$ satisfying the target strengths.

\section{Acknowledgements}

This work was carried out under the project supported by the New Energy and Industrial Technology Development Organization (NEDO) of Japan. The authors would like to express our hearty thanks to NEDO for the financial support. The authors would also like to thank Mr. H. Tanaka and Dr. C. L. Ma for experimental assistance and useful comments. The authors would also like to thank their colleagues of JUTEMI for technical support during this work.

\section{REFERENCES}

1) P. R. Subramanian, M. G. Mendiratta and D. M. Dimiduk: JOM Overview 48 (1996) 33-38.

2) J. R. Davis: ASM SPECIALTY HANDBOOK "Heat-Resistant Materials", (ASM International, OHIO, 1997) 361-382.

3) M. R. Jackson, B. P. Bewlay, R. G. Rowe, D. W. Skelly and H. A. Lipsitt: JOM Overview 48 (1996) 39-44.

4) T. Narita: Proc. 11th Int. Symp. on Ultra-high Temperature Materials, 2001 in Tajimi, (JUTEM-JUTEMI) 78-88.

5) W. Y. Kim, H. Tanaka and S. Hanada: Mater. Trans. 43 (2002) 14151418.

6) W. Y. Kim, H. Tanaka and S. Hanada: J. Alloys Compounds 333 (2002) 170-178.

7) N. Aritomi: Trans. NRIM 21 (1979) 18.

8) H. Tanaka, Y. Tan, C. L. Ma, A. Kasama and R. Tanaka: Report of the 123rd Committee on Heat-resisting Materials and Alloys, Japan Society for the Promotion of Science 41 (2000) 223-227.

9) C. L. Ma, A. Kasama, Y. Tan, H. Tanaka, R. Tanaka, Y. Mishima and S. Hanada: Report of the 123rd Committee on Heat-Resisting Materials and Alloys, Japan Society for the Promotion of Science 40 (1999) 349360.

10) P. R. Subramanian, T. A. Parthasarathy, M. G. Mendiratta and D. M. Dimiduk: Scr. Metall. Mater. 32 (1995) 1227-1232.

11) Binary Alloy Phase Diagrams, ed. by T. B. Massalski, (ASM, Metals Park, OH, 1986) 1696.

12) M. G. Mendiratta and D. M. Dimiduk: Mater. Res. Soc. Symp. Proc., Materials Research Society, Pittsburgh, PA 133 (1989) 441-446.

13) Y. Kagawa and H. Hatta: Tailoring Ceramic Composites, (AGNE Shofusha, Tokyo), (1990) 96-119.

14) R. Nekkanti and D. M. Dimiduk: Intermetallic Matrix Composites, D. L. Anton, R. McMeeking, D. Miracle and P. Martin, eds.,: Mater. Res. Soc. Symp. Proc. 194 (1990) 175.

15) S. Hanada: NEDO Report on Advanced Processing Technology for the Component Materials of Refractory Metals, (1998) 75-90.

16) M. Fujikura: unpublished work.

17) M. E. Schlesinger, H. Okamoto, A. B. Gokhale and R. Abbaschian: J. Phase Equil. 14 (1993) 502.

18) H. Mehrer (Ed.): Diffusion in Solid Metals and Alloys, Group III: Crystal and Solid State Physics, Numerical Data and Functional Relationships in Science and Technology, New Series 26 (1990).

19) G. L. Erickson: JOM 47 (1995) 36-39. 